\title{
AN ASSESSMENT OF HEALTH IMPLICATIONS OF NATURAL RADIOACTIVITY IN THE TAR SAND DEPOSIT OF ONDO STATE, SOUTHWESTERN NIGERIA
}

\author{
Adekunle Adedapo Oyawale ${ }^{1,+}$, Taiwo Rufus Ajayi ${ }^{1}$ and Musibau Kewulere Fasasi ${ }^{2}$ \\ ${ }^{1}$ Department of Geology and ${ }^{2}$ Centre for Energy Research and Development, \\ Obafemi Awolowo University, Ile-Ife, Nigeria.
}

(Submitted: 30 April 2004; Accepted: 16 June 2004)

\begin{abstract}
Gamma ray spectrometric and Energy-dispersive X-ray fluorescence analyses were carried out on samples of bituminous sand deposits of Ondo State. The objectives were to determine the presence and level of radioactivity; assess the impact of radioactivity on the environment and provide a geochemical baseline data for its exploitation.

The average specific activity concentrations obtained for Bi-214, T1-208 and Ra-226 in the overburden were $165.64 \pm 2.91$, $150.25 \pm 2.91$ and $60.97 \pm 2.27 \mathrm{BqKg}^{-1}$ respectively. Only Ra-226 with a range of $(18.12 \pm 3.53$ to $36.13 \pm 3.15) \mathrm{BqKg}^{-1} \mathrm{and}$ $\mathrm{Pb}-214$ with a range of $(17.17 \pm 0.46$ to $31.01 \pm 0.84) \mathrm{BqKg}^{-1}$ were detected in the bituminous sands. The calculated average dose rate in the overburden and the bituminous sands were $68.49 \mathrm{nGyhr}^{-1}$ and $8.66 \mathrm{nGyhr}^{-1}$ respectively. The mean equivalent doses in the overburden and the bituminous sands were about $0.59 \mathrm{mSvyr}^{-1}$ and $0.07 \mathrm{~m}$

In general, the study confirmed the presence of radionuclides in the overburden and the bituminous sands but their activity levels are within the background values. The calculated radiation values fall below the recommended exposure limit to the populace and thus are not expected to constitute any health hazard.
\end{abstract}

Keywords: Health implications, radioactivity, tar/bituminous sand, dose-limits.

\section{Introduction}

Renewed interest in the exploration and exploitation of the vast bituminous sand deposit of Nigeria and recent reported cases of possible high levels of radioactive materials in some bituminous nodules in Chez Republic (Bohdan et al., 1999) emphasizes the need for new studies on the presence and level of radioactivity within the bituminous sand of Ondo state.

Tar sand deposits with enormous reserves are known to occur within a belt that cuts across Lagos, Ogun, Ondo and Edo States in South-western Nigeria. Outcrops however, cover an area of $120 \mathrm{~km}$ by $6 \mathrm{~km}$ in an East-West belt (Fig. 1). Tar sands are composed of sands, heavy oil (bitumen) and mineral rich clay in various proportions (Adegoke et al., 1980). The heavy oil in the tar sand is a viscous complex mixture of hydrocarbons and other heterocyclic substances.

Radioactive elements occur in trace amounts in all rocks and minerals and are readily detectable by the gamma radiation emitted during their decay. Natural radioactivity is associated with natural sources such as uranium deposits, oil and natural gas fields (Boyle, 1982). The primary source of radiation received by humans is from the store of natural radioactivity in soils, those due to medical examination/ therapy and artificial radionuclides produced by thermonuclear testing. All over the world, radioactivity measurements have revealed a lot of useful information about radiation levels in natural and polluted environments. Exter- nal radiation exposures from naturally occurring radionuclides have been reported to contribute about half of the average annual dose to humans from all radiation sources (National Research Council, 1988). The health effect of radon is a subject of much debate; recent reports from the U.S indicate that a portion of the population may be exposed to potentially harmful level of radiation from radon progeny. Radon produces two short-lived isotopes of polonium, ${ }^{218} \mathrm{Po}$ and ${ }^{214} \mathrm{Po}$, which are non-gaseous and tend to attach to particulates and aerosols in the air and can be inhaled. In such condition, it lodges in the lungs and can cause damage to the lungs through the emission of alpha radiation as it decays. Gates and Gundersen (1992) showed that the decay of short-lived daughters of some radionuclides especially ${ }^{222} \mathrm{Rn}$ causes induced cancer and was responsible for an estimated 15,000 to 20,000 deaths in the U.S.

Up till now, no work has been reported on the health implications of the natural radioactivity distribution in the tarsand deposits of Ondo State and the environmental implications for its exploration and exploitation. The main objective of this study is to determine the absorbed doses and dose equivalents due to selected radionuclides in both the soil and bituminous sand samples, thus to assess their health impact.

\section{Geology and Stratigraphy}

The study area falls within the Nigerian sector of the Dahomey basin. Klemme (1975) showed that it is a coastal, sedi- 


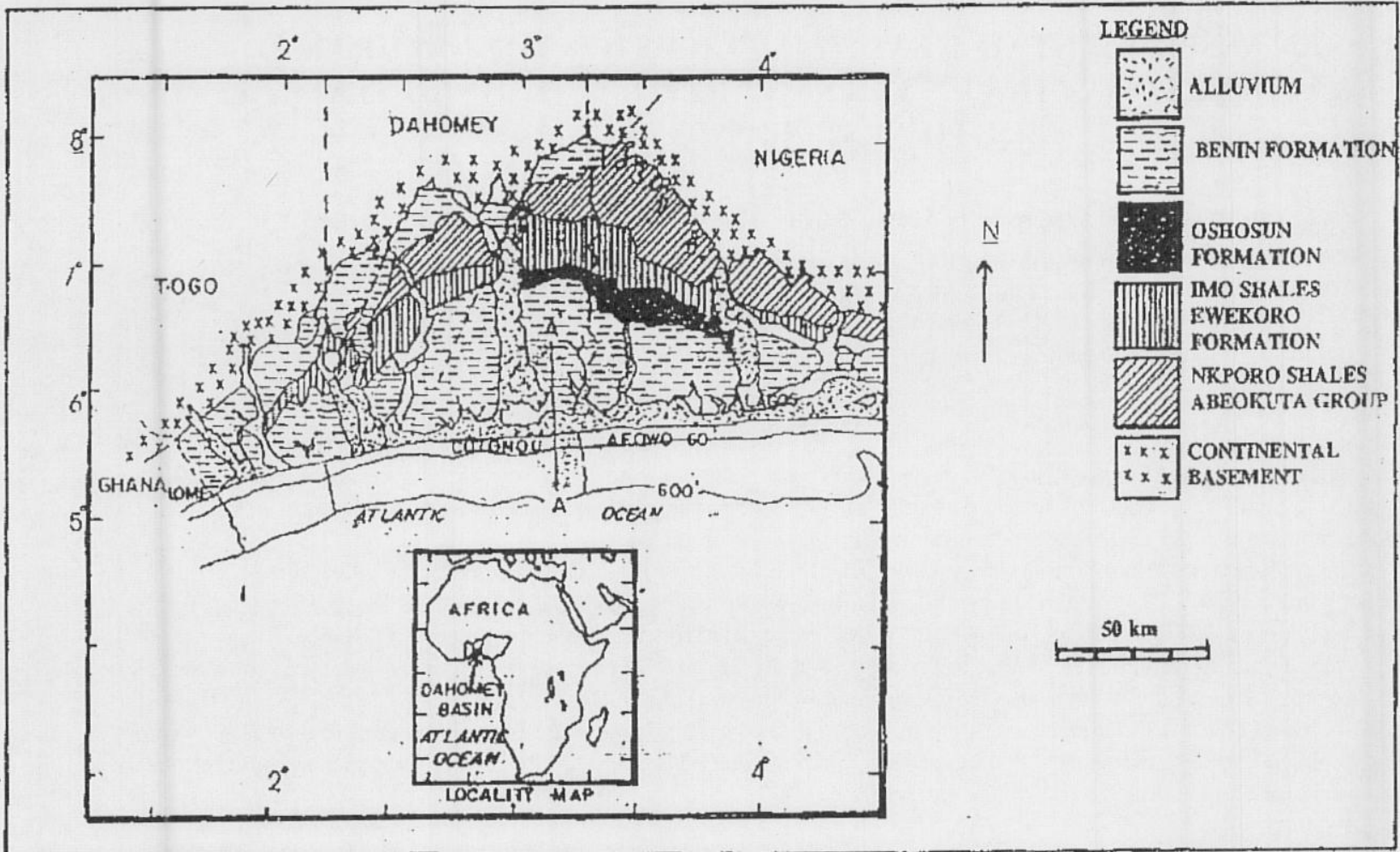

Figure 1: Regional Geological map of Dahomey Basin (after Adegoke et al., 1980)

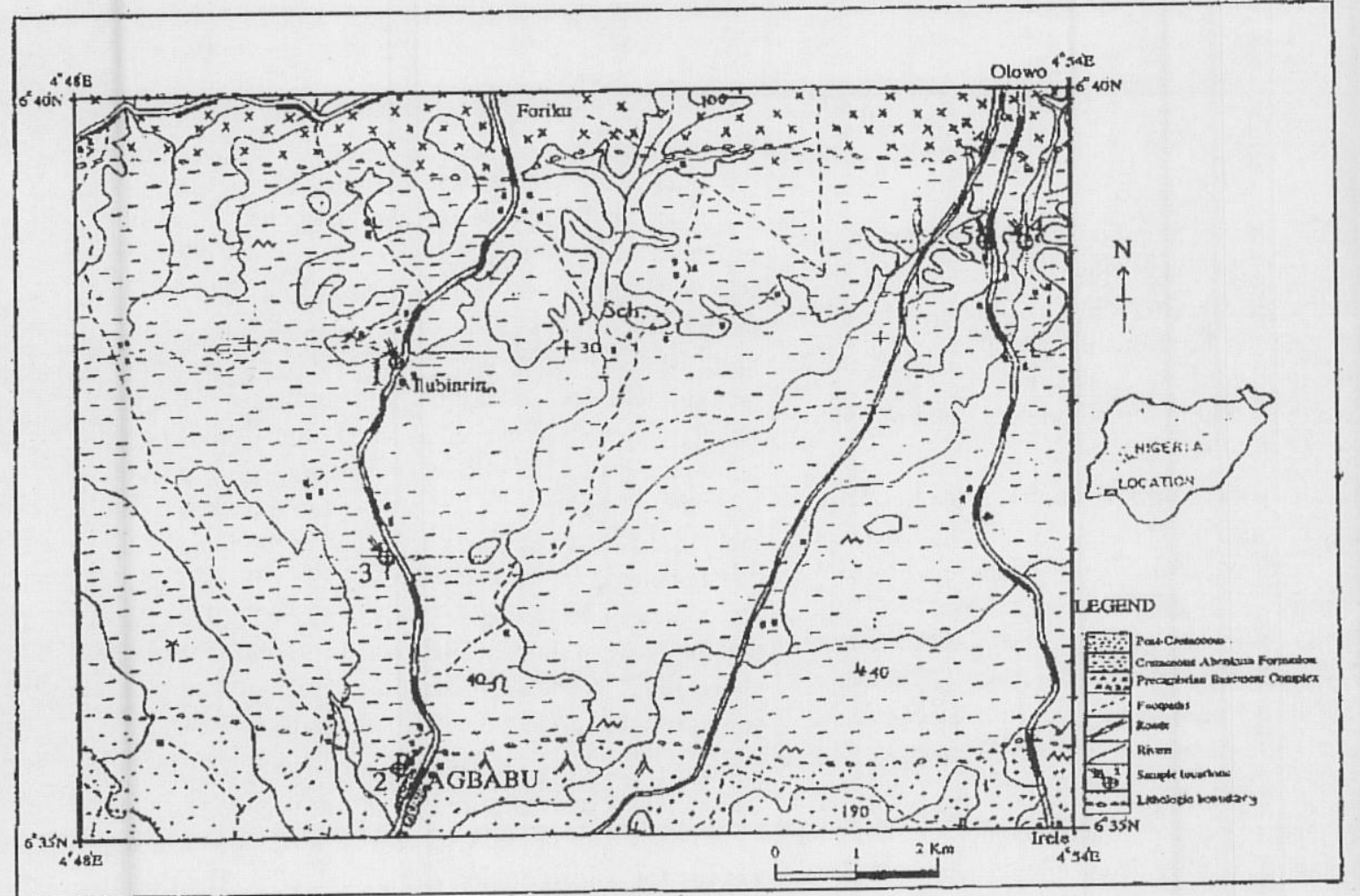

Figure 2: Sample location map of study area (after Oyawale, 2003)

mentary, marginal (Type 5) pull apart basin. The basin extends from Ghana-Ivory coast boundary across Togo, and republic of Benin to Western Nigeria. Durham and Picket (1966) subdivided the basins sedimentary fill into three lithological units. The geology of the Nigerian sector of the Dahomey basin was later reviewed by Omatsola and
Adegoke (1981). They showed that the bitumen were found impregnating sedimentary deposits previously referred to as the Abeokuta Formation in the literature. They recognized three Formations belonging to the Abeokuta group. These are Ise, Afowo and Araromi Formations. The main habitat, for the bituminous sands are the Afowo Formation, 
which is made up of a thick sequence of sands, interbedded with organic shale and siltstones. The tar bearing sands occur as two distinct stratigraphic bands (X and Y) separated by a uniformly thick oil shale (Enu, 1985). The thickness of the oil shale ranges between 6 and $15 \mathrm{~m}$, and the average thickness of the tar sand horizons is about $12 \mathrm{~m}$.

\section{Materials and Methods}

The study area falls within latitudes $6^{\circ} 35^{\circ}$ and $6^{\circ} 39^{\prime} \mathrm{N}$ and longitudes $4^{\circ} 48^{\prime}$ and $4^{\circ} 54^{\prime} \mathrm{E}$. Ten surface and pit samples were collected from five locations (Ilubinrin, Agbabu, Mile 2, Camp Looda 1 and Camp Looda 2 (Fig. 2). The samples include both the bituminous sands and the overlying materials generally referred to as the overburden.

For the purposes of gamma-ray spectrometric analysis, except for samples $2 \mathrm{~A}$ and $3 \mathrm{~A}$ that are viscous bitumen, the samples were homogenized and dried in free air until constant weight was achieved. The samples were sealed (air tight) for a minimum of 28 days to attain secular equilibrium, which is done to prevent the gaseous daughters of the two natural decay series headed by U-238 and Th-232. Energy and efficiency calibrations were done using a wellcalibrated mixed source soil standard obtained from the Federal Radiation Protection Services (FRPS), University of Ibadan, Nigeria and traceable to the standard calibration laboratory of the IAEA. These calibrations aided the identification and quantification of the radionuclides present in each sample. The analysis was done using a Gamma ray spectrometer fitted with a calibrated Canberra vertical coaxial high purity Germanium Detector System located at the laboratory of the Centre for Energy, Research and Development (CERD), Obafemi Awolowo University, Ile-Ife. The spectra for each sample was measured by counting for 36,000 secs using an HPGe detector that was shielded by a $5 \mathrm{~cm}$ thick lead castle which was constructed to maintain low background radiation level. Also, an empty container was counted to serve as background count. The soil standard that contains "certified" radioactivity concentrations due to ${ }^{238} \mathrm{U},{ }^{232} \mathrm{Th}$ and ${ }^{40} \mathrm{~K}$ (by weight) was also counted for a minimum of $36,000 \mathrm{~s}$ in accordance with standard practice (IAEA, 1989). The spectra produced were analyzed using a computer program Sampo-90, which matched $\gamma$-energies at various energy levels to a library of possible radioisotopes.

For the purposes of EDXRF study, about $10 \mathrm{~g}$ of the air dried samples were disaggregated by pestle and mortar and later pulverized in a disc mill. Except for the sticky tarsand, each sample powder was homogenized and quartered to obtain a representative portion. Pellets of $19 \mathrm{~mm}$ diameter were prepared from $0.3 \mathrm{~g}$ powder mixed with cellulose in a 1:2 weight ratio and pressed at 5 tons. Measurements were made at the Centre for Energy, Research and Training (CERT), Ahmadu Bello University, Zaria, using an annular $25 \mathrm{mCi}{ }^{109} \mathrm{Cd}$ and ${ }^{55} \mathrm{Fe}$ excitation sources. The ${ }^{109} \mathrm{Cd}$ emits Ag-K X-rays (22.1 KeV) and ${ }^{55} \mathrm{Fe}$ emits Mn-K X-rays $(5.89 \mathrm{KeV})$ so that all elements with low characteristics excitation energies were detectable in the samples.

The corresponding absorbed dose rates were calculated using the relationship derived by Beck et al., (1972), which is given as:
$D=0.042 A_{c(K)}+0.429 A_{c(\mathrm{C})}+0.666 A_{C(\mathrm{Th})}(\mathrm{nGyhr}-1)$

where,

$D=$ the absorbed dose rate in air

$A_{C(K)}=$ Activity concentration of potassium $\left(\mathrm{BqKg}^{-1}\right)$

$A_{C(C)}=$ Activity concentration of uranium $\left(\mathrm{BqKg}^{-1}\right)$

$A_{C(T H)}=$ Activity concentration of thorium $\left(\mathrm{BqKg}^{-1}\right)$

The Dose equivalent in $\left(\mathrm{mSvyr}^{-1}\right)$ was obtained by converting the absorbed dose in $\mathrm{Gyhr}^{-1}$ to $\mathrm{mSvyr}^{-1}$ thus:

$X\left(\mathrm{nGyhr}^{-1}\right)=\left(X^{*} 24 \mathrm{hrs} * 365\right.$ days $\left./ 1000000\right) \mathrm{mSvyr}^{-1}$

\section{Results and Discussions}

Table 1 shows the results of the various radioisotopes identified and their specific activity concentration in the soil/ bituminous samples. The radionuclides identified and quantified from the gamma ray spectra are decay daughter products of naturally occurring radioactive elements ${ }^{238} \mathrm{U}$ and ${ }^{232} \mathrm{Th}$. The other naturally occurring but non-series radioactive isotope, ${ }^{40} \mathrm{~K}$ whose photo peak was identified could not be quantified. In spite of its ubiquitous occurrence in most environments, ${ }^{40} \mathrm{~K}$ were observed to occur below the limit of detection of our gamma spectrometer. Feldspars and mica have been reported to occur in very small amount; also clays are not present in high percentage in the tar sands $<5 \%$ (Adegoke et al., 1980). All these are potential sites for $\mathrm{K}$, the absence of which could result in low value of ${ }^{40} \mathrm{~K}$ in the measured samples.

The average specific activity concentrations of ${ }^{214} \mathrm{Bi},{ }^{208} \mathrm{Tl}$ and ${ }^{226} \mathrm{Ra}$ in the overburden are $165.64 \pm 9.56 \mathrm{BqKg}^{-1}$, $150.25 \pm 10.36 \mathrm{BqKg}^{-1}$ and $60.97 \pm 4.92 \mathrm{BqKg}^{-1}$. In the bituminous sands/viscous tar $\mathrm{Pb}-214$ and $\mathrm{Ra}-226$ showed average values of $24.09 \pm 0.65 \mathrm{BqKg}^{-1}$ and $25.25 \pm 3.16$ $\mathrm{BqKg}^{-1}$ respectively. The other radionuclides were below the detectable limits of the instrument. The activity concentrations of the radionuclides vary partly with depth and partly with lithology and the values are within the same range when compared with values obtained for similar radionuclides on non-mineralized soils from Kanawa uranium mineralization area in N.E. Nigeria (Funtua, 1994), with $\mathrm{U}$, Th, ${ }^{226} \mathrm{Ra}$ and ${ }^{210} \mathrm{~Pb}$ having $30-71 \mathrm{ppm},<250 \mathrm{BqKg}^{-1}$, $<300 \mathrm{BqKg}^{-1}$ and $<300 \mathrm{BqKg}^{-1}$ respectively.

The low level of radioactive elements in the bituminous sand correlates with the results of natural gamma-ray logs earlier reported by (Adegoke et al., 1980). They observed a low magnitude of gamma deflection opposite clean sands, a high magnitude of gamma deflection opposite clay/shale horizons and an invariably low gamma-ray response in the zone of bitumen-saturated sands.

Tables 2 and 3 show the summary of elemental concentration in the overburden and the bituminous sands respectively. In the overburden, the values of Th varied from $11 \pm$ $4 \mathrm{ppm}$ to $20 \pm 6 \mathrm{ppm}$ with an average of $16.6 \pm 4.22 \mathrm{ppm}$ while $\mathrm{U}$ varied from $12 \pm 3 \mathrm{ppm}$ to $15 \pm 3 \mathrm{ppm}$ with an average of $13.2 \pm 1.2 \mathrm{ppm}$. In the bituminous sands, the values of Th varied from $13 \pm 5 \mathrm{ppm}$ to $32 \pm 6 \mathrm{ppm}$ while $\mathrm{U}$ 
Table 1: Concentration of radionuclides in $\left(\mathrm{BqKg}^{-1}\right)$

\begin{tabular}{|l|l|l|l|c|c}
\hline Sample & \multicolumn{3}{|c|}{${ }^{238} \mathrm{U}$} & \multicolumn{2}{c}{${ }^{232} \mathrm{Th}$} \\
\hline & ${ }^{214} \mathrm{Bi}$ & ${ }^{214} \mathrm{~Pb}$ & ${ }^{220} \mathrm{Ra}$ & ${ }^{208} \mathrm{Tl}$ & ${ }^{228}$ \\
\hline Lateritic Soil (1A) & $263.83 \pm 4.25$ & $107.60 \pm 2.38$ & $93.98 \pm 1.20$ & $152.92 \pm 6.62$ & $73.17 \pm 8.84$ \\
\hline Clayey Soil (1B) & $97.87 \pm 1.89$ & $59.62 \pm 1.53$ & $69.17 \pm 4.02$ & $61.86 \pm 2.28$ & $62.24 \pm 8.52$ \\
\hline Sandy clay Soil (1C) & $41.75 \pm 0.85$ & $17.01 \pm 0.59$ & $71.61 \pm 1.99$ & $353.78 \pm 15.19$ & $67.81 \pm 8.96$ \\
\hline Lateritc Soil (4A) & $275.22 \pm 4.67$ & $60.71 \pm 1.56$ & $47.67 \pm 2.83$ & $63.02 \pm 2.65$ & $99.25 \pm 11.4 \ell$ \\
\hline Loose sand (5B) & $149.58 \pm 2.89$ & $31.91 \pm 0.97$ & $22.42 \pm 1.33$ & $119.50 \pm 5.78$ & $15.43 \pm 2.61$ \\
\hline Bituminous sand (1D) & - & $17.77 \pm 0.46$ & $36.13 \pm 3.15$ & - & - \\
\hline Viscous tar (2A) & - & - & $18.12 \pm 3.53$ & - & - \\
\hline Viscous tar (3A) & - & $31.01 \pm 0.84$ & $27.83 \pm 3.53$ & - & - \\
\hline Bituminous sand (4B) & - & - & $18.92 \pm 2.46$ & - & - \\
\hline Bituminous sand (5A) & - & - & - & - & - \\
\hline
\end{tabular}

Table 2: Elements Concentration in the Overburden (Values in ppm except where indicated).

\begin{tabular}{|c|c|c|c|c|c|c|}
\hline \multirow[b]{2}{*}{ Elements } & \multicolumn{6}{|c|}{ Samples } \\
\hline & $\begin{array}{c}1 \mathrm{~A} \\
\text { Lateritic soil }\end{array}$ & \begin{tabular}{l}
\multicolumn{1}{c}{ 1B } \\
Reddish \\
brown clayey \\
soil
\end{tabular} & $\begin{array}{c}1 \mathrm{C} \\
\text { Sandy clay }\end{array}$ & $\begin{array}{l}4 \mathrm{~A} \\
\text { Lateritic } \\
\text { top soil }\end{array}$ & $\begin{array}{l}5 \mathrm{~B} \\
\text { Loose medium } \\
\text { grained sand }\end{array}$ & $\begin{array}{l}\text { Limit of } \\
\text { detection } \\
\text { (LOD) }\end{array}$ \\
\hline K (wt)\% & $0.31 \pm 0.08$ & $0.55 \pm 0.23$ & $0.52 \pm 0.22$ & $0.72 \pm 0.24$ & $0.80 \pm 0.24$ & 0.30 \\
\hline $\mathrm{Ca}(w t) \%$ & $0.20 \pm 0.06$ & $0.39+0.05$ & $0.38 \pm 0.05$ & $0.54 \pm 0.08$ & $0.49 \pm 0.06$ & 0.144 \\
\hline & $320 \pm 20$ & $470+40$ & $500 \pm 40$ & $660 \pm 50$ & $360 \pm 40$ & 0.08 \\
\hline $\mathrm{Mn}$ & $200 \pm 10$ & $60+10$ & $70 \pm 10$ & $1300 \pm 100$ & 20 LOD & 0.039 \\
\hline $\mathrm{Fe}(w t) \%$ & $24.6 \overline{3} \pm 0.28$ & $12.18+0.13$ & $15 . \overline{8} 8 \pm 0.16$ & $19.32 \pm 0.19$ & $0.62 \pm 0.03$ & 0.27 \\
\hline $\mathrm{Zn}$ & $57 \pm 1 \overline{0}$ & $52+10$ & $4.3 \pm 8$ & $52 \pm 10$ & $26 \pm \overline{8}$ & 10 \\
\hline $\mathrm{Rb}$ & $11+3$ & $15 \pm 4$ & $19 \pm 4$ & $12+3$ & $10 \pm 2$ & 0.18 \\
\hline $\mathrm{Sr}$ & $126 \pm 4$ & $248 \pm 6$ & $161 \pm 5$ & $74+5$ & $135 \pm 4$ & 2.9 \\
\hline $\mathrm{Y}$ & $9 \pm 2$ & $19 \pm 3$ & $12 \pm 3$ & $12+3$ & $33 \pm 3$ & 5.2 \\
\hline $\mathrm{Pb}$ & $68 \pm 14$ & $53 \pm 18$ & $43+10$ & $63+10$ & $30+8$ & 0.18 \\
\hline Ta & $<\mathrm{LO}$ & $<\mathrm{LO}$ & $<\mathrm{LOD}$ & $<\mathrm{LO}$ & $<\mathrm{LOD}$ & 0.13 \\
\hline W & $<$ LOD & $<$ LOD & $<\mathrm{LOD}$ & $<$ LOD & $<$ LOD & 0.18 \\
\hline Th & $18 \pm 6$ & $20 \pm 6$ & $16 \pm 5$ & $18+6$ & $11 \pm 4$ & 0.24 \\
\hline $\mathrm{U}$ & $12+3$ & $12+3$ & $13+4$ & $15+3$ & $14+4$ & 0.41 \\
\hline $\mathrm{Zr}$ & $346 \pm 5$ & $446 \pm 6$ & $365 \pm 6$ & $255+5$ & $223 \pm 4$ & 0.85 \\
\hline $\mathrm{Nb}$ & $15 \pm 2$ & $19 \pm 2$ & $10 \pm 2$ & $18 \pm 3$ & $6 \pm \overline{2}$ & 0.10 \\
\hline
\end{tabular}

$<\mathrm{LOD}=$ Value lower than limit of detection

Table 3: Elements Concentration in Bituminous sands (Values in ppm except where in dicated)

\begin{tabular}{|c|c|c|c|c|c|}
\hline \multirow[t]{2}{*}{ El ements } & \multicolumn{5}{|c|}{ Samples } \\
\hline & $\begin{array}{l}\text { 1D } \\
\text { Bituminous sands }\end{array}$ & $\begin{array}{c}2 \mathrm{~A} \\
\text { Viscous tar }\end{array}$ & $\begin{array}{l}3 \mathrm{~A} \\
\text { Viscous tar }\end{array}$ & $\begin{array}{l}\text { 4B } \\
\text { Slightly } \\
\text { impregnated tar } \\
\text { sand }\end{array}$ & $\begin{array}{l}5 \mathrm{~A} \\
\text { Highly impregnated } \\
\text { bituminous sand }\end{array}$ \\
\hline $\mathrm{K}(w t) \%$ & $0.56 \pm 0.22$ & $0.11<\mathrm{LOD}$ & $0.06 \mathrm{LOD}$ & $0.75 \pm 0.25 \quad 0.44$ & $0.08 \mathrm{LOD}$ \\
\hline $\mathrm{Ca}(\mathrm{wt}) \%$ & $0.54 \pm 0.12$ & $0.10<$ LOD & $0.22 \pm 0.04$ & $\pm 0.0 \overline{7}$ & $0.06 \mathrm{LOD}$ \\
\hline & $400 \pm 40$ & $3 \mathrm{LOD}$ & $30 \pm \overline{4}$ & $\overline{230} \pm 40$ & $20 \pm 1$ \\
\hline $\mathrm{Mn}$ & $30 \pm 10$ & 10 LOD & 20 LOD & $20 \mathrm{LOD}$ & 30 LOD \\
\hline $\mathrm{Fe}(w t) \%$ & $3.3 \overline{5} \pm 0.06$ & $0.04 \pm 0.01$ & $0.52 \pm 0.06$ & $0.76 \pm 0.04$ & $0.03 \pm 0.003$ \\
\hline $\mathrm{Zn}$ & $30 \pm 12$ & $51 \pm 10$ & $7 \pm 2$ & $30 \pm 12$ & 3 LOD \\
\hline $\mathrm{Rb}$ & $8 \pm 3$ & $24 \pm 5$ & $2 \mathrm{LOD}$ & $8 \pm 2$ & $1 \mathrm{LOD}$ \\
\hline $\mathrm{Sr}$ & $17 \pm 3$ & $19 \pm 3$ & $25 \pm 1$ & $14+3$ & $4 \pm 0.40$ \\
\hline $\mathrm{Y}$ & $10+3$ & $18+4$ & $4+1$ & $6+3$ & $1 \mathrm{LOD}$ \\
\hline $\mathrm{Pb}$ & $33 \pm 7$ & $69 \pm 18$ & $6 \mathrm{LOD}$ & $31+6$ & $4 \mathrm{LOD}$ \\
\hline $\mathrm{Ta}$ & $<\mathrm{LO} D$ & $<\mathrm{LOD}$ & $<\mathrm{LOD}$ & $<L O D$ & $<$ LOD \\
\hline W & $<$ LOD & $<$ LOD & $<\mathrm{LOD}$ & $<$ LOD & $<\mathrm{LOD}$ \\
\hline Th & $14 \pm 6$ & $32 \pm 8$ & $<$ LOD & $13+5$ & $<\mathrm{LOD}$ \\
\hline $\mathrm{U}$ & $9 \pm 3$ & $33 \pm 6$ & $4 \pm 1$ & $10+3$ & $<\mathrm{LOD}$ \\
\hline $\mathrm{Zr}$ & $13 \overline{6} \pm 3$ & $18 \pm 2$ & $76 \pm 1$ & $75+3$ & $15 \pm 1$ \\
\hline $\mathrm{Nb}$ & $6 \pm 2$ & $14 \pm 2$ & $1 \mathrm{LOD}$ & $4 \pm 1$ & 1 LOD \\
\hline
\end{tabular}


Table 4: Calculated Absorbed Dose Rate of the Lateritic Overburden.

\begin{tabular}{|c|c|c|c|c|c|}
\hline $\begin{array}{l}\text { Sample } \\
\text { no }\end{array}$ & $\begin{array}{l}\text { Sample } \\
\text { Description }\end{array}$ & $\begin{array}{c}\mathrm{Ac}(\mathrm{U}) \\
\mathrm{Ra}-226 \\
\left(\mathrm{Bqkg}^{-1}\right) \\
\end{array}$ & $\begin{array}{l}\mathrm{A}_{\mathrm{C}}(\mathrm{Th}) \\
\mathrm{Ac}-228 \\
\left(\mathrm{Bqkg}^{-1}\right)\end{array}$ & $\begin{array}{l}\text { Absorbed } \\
\text { dose rate } \\
\left(\mathrm{nGyhr}^{-1}\right)\end{array}$ & $\begin{array}{l}\text { Dose } \\
\text { equivalents } \\
\left(\mathrm{mSvyr}^{-1}\right)\end{array}$ \\
\hline $1 \mathrm{~A}$ & $\begin{array}{l}\text { Lateritic } \\
\text { Top-soil }\end{array}$ & $93.98 \pm 1.20$ & $73.17 \pm 8.84$ & 89.05 & 0.78 \\
\hline 1B & $\begin{array}{l}\text { Reddish brown } \\
\text { clayey soil }\end{array}$ & $69.17 \pm 4.02$ & $62.24 \pm 8.53$ & 71.12 & 0.62 \\
\hline $1 \mathrm{C}$ & Sandy clay & $71.61 \pm 1.99$ & $67.81 \pm 8.90$ & 75.88 & 0.66 \\
\hline $4 \mathrm{~A}$ & $\begin{array}{l}\text { Lateritic } \\
\text { Top- soil }\end{array}$ & $47.67 \pm 2.83$ & $99.25 \pm 11.46$ & 86.55 & 0.76 \\
\hline $5 \mathrm{~B}$ & $\begin{array}{l}\text { Loose medium } \\
\text { grained sand. }\end{array}$ & $22.42 \pm 1.33$ & $15.43 \pm 2.61$ & 19.89 & 0.17 \\
\hline
\end{tabular}

Table 5: Calculated Absorbed Dose Rate of bituminous sand (nGyhr-1)

\begin{tabular}{|c|l|c|c|c|l|}
\hline $\begin{array}{l}\text { Sample } \\
\text { no }\end{array}$ & $\begin{array}{l}\text { Sample } \\
\text { Description }\end{array}$ & $\begin{array}{l}\mathrm{Ac}(\mathrm{U}) \\
\mathrm{Ra}-226 \\
\left(\mathrm{Bqkg}^{-1}\right)\end{array}$ & $\begin{array}{l}\mathrm{A}_{\mathrm{C}}(\mathrm{Th}) \\
\mathrm{Ac}-228 \\
\left(\mathrm{Bqkg}^{-1}\right)\end{array}$ & $\begin{array}{l}\text { Absorbed } \\
\text { dose rate } \\
\left(\mathrm{nGyhr}^{-1}\right)\end{array}$ & $\begin{array}{l}\text { Dose } \\
\text { equivalents } \\
\left(\mathrm{mSvyr}^{-1}\right) .\end{array}$ \\
\hline 1D & Bituminous sand & $36.13 \pm 3.15$ & - & 15.49 & 0.135 \\
\hline 2D & Viscous tar & $18.12 \pm 3.52$ & - & 7.77 & 0.068 \\
\hline 4B & $\begin{array}{l}\text { Viscous tar } \\
\text { Slightly impregnated } \\
\text { bituminous sand }\end{array}$ & $27.13 \pm 3.35$ & - & 11.94 & 0.105 \\
\hline 5A & $\begin{array}{l}\text { Highly impregnated } \\
\text { bituminous sand }\end{array}$ & - & - & 8.12 & 0.07 \\
\hline
\end{tabular}

Table 6: Dose limits and their biological effects

\begin{tabular}{|c|c|c|}
\hline Radiation dose rate & $\begin{array}{l}\text { Duration of } \\
\text { exposure }\end{array}$ & Likely effects/implications \\
\hline $10,000 \mathrm{mSv}$ & $\begin{array}{l}\text { Short-term } \\
\text { dose }\end{array}$ & Immediate illness and subsequent death within a few weeks. \\
\hline $1,000 \mathrm{mSv}$ & $\begin{array}{l}\text { Short-term } \\
\text { dose }\end{array}$ & $\begin{array}{l}\text { Nausea and decreased white blood cell, but not death. Above this, } \\
\text { severity of illness increase with dose. }\end{array}$ \\
\hline $50 \mathrm{mSv} / \mathrm{yr}$ & Over 5years & $\begin{array}{l}\text { Conservatively, the lowest dose rate where there is any evidence of } \\
\text { cancer being caused. Above this, the probability of cancer occurrence } \\
\text { increases with dose. }\end{array}$ \\
\hline $20 \mathrm{mSv} / \mathrm{yr}$ & Over 5years & $\begin{array}{l}\text { Limit for nuclear industry employees and uranium miners, who are } \\
\text { closely monitored. }\end{array}$ \\
\hline $2 \mathrm{mSv} / \mathrm{yr}$ (approx) & & $\begin{array}{l}\text { Normal background radiation from natural sources, including an } \\
\text { average of } 0.7 \mathrm{mSv} / \mathrm{yr} \text { from radon in air. }\end{array}$ \\
\hline $0.3-0.6 \mathrm{mSv} / \mathrm{yr}$ & & Artificial sources of radiation, mostly medical equipment. \\
\hline
\end{tabular}

Source: (ICRP, 2002) Uranium information center. 
varied from $4 \pm 1 \mathrm{ppm}$ to $33 \pm 6 \mathrm{ppm}$. This confirms the presence of these elements in both the overburden and the bituminous sands.

The results of the absorbed dose rate vary between 19.89 and 89.05 nGyhr $^{-1}$ with a mean of 68.49 nGyhr $^{-1}$ in the overburden while the average value of absorbed dose rate in the bituminous sand is $8.66 \mathrm{nGyhr}^{-1}$. (Tables 4 and 5). The absorbed dose rate itself does not give an indication of possible biological effects until it is converted to the dose equivalent, which is measured in Sieverts (Sv). The mean dose equivalents are $0.59 \mathrm{mSvyr}^{-1}$ in the overburden and $0.076 \mathrm{mSvyr}^{-1}$ in the bituminous sands. On the risk of cancer-induction due to exposure of the population, observational evidence shows that radiation induced cancer in humans comes largely from exposures due to large doses over a short period of time. However, for setting of environmental standards and for gauging the consequences of exposures routinely received by the general public, the most important doses are relatively small doses received over long period of time. Comparing the results of this study with the dose limit set by the International Commission on Radiological Protection (ICRP) in Table 6, the calculated dose equivalent falls below harmful level which is $1 \mathrm{mSv} / \mathrm{yr}$ to the general public and $20 \mathrm{mSv} / \mathrm{yr}$ for radiation workers in most environment.

\section{Conclusions}

The results of gamma spectrometer and energy dispersive $\mathrm{XRF}$ analyses showed that measurable traces of radioisotopes that belong to ${ }^{238} \mathrm{U}$ and ${ }^{232} \mathrm{Th}$ are present in both the overburden and the bituminous sands. The result shows that the dose equivalents at a distance of $1 \mathrm{~m}$ from the ground are $0.59 \mathrm{mSvyr}^{-1}$ in the overburden while it is $0.076 \mathrm{mSvyr}^{-1}$ in the bituminous sands. This is still below harmful dose to man. However, the mode of exploitation and extraction could contribute to an increase in the rate of release of the harmful radon gas and could therefore be an important health factor in the future. Open cast mining might expose and concentrate Radon in the overburden during excavation, which may lead to significant health hazards. For low levels of radiation exposure, the biological effects are so small they may not be detectable. Radiation protection standards assume however, that the effect is directly proportional to the dose, even at low levels. A baseline study of this nature, coupled with data from other sampling media such as well water, stream water and vegetation could help the government to enact policies on safety and monitoring when full exploitation begins.

\section{Aknowledgements}

The authors are grateful to the Center for Energy, Research and Developments (CERD), the Department of Geology, Obafemi Awolowo University Ile- Ife and the International Atomic Energy, IAEA, Vienna, for the various facilities made available for this work.

\section{REFERENCES}

Adegoke. O.S., Ako. B.D., Enu. E.I., Afonja, A.A. and Ajayi, T.R., 1980. Geotechnical Investigations of the Ondo State Bituminous Sands, Vol
1: Geology and Reserves Estimate 'Unpub. Report.' Geological Consultancy Unit, Department of Geology, University of Ife, Ile-Ife. 257 pp

Beck, H.L., Decampo and Gologak, J., 1972. In-Situ Ge-Li and NAI(TI) Gamma ray spectrometry. HASL -258 .

Bohdan, K., Karel, Z., Jorge, S., Jan, J., Stanislav, P. and Jiri, K., 1999. Bitumen in the Late Variscan Hydrothermal Vein-Type Uranium Deposit in Czech Republic: Sources, Radiation-Induced Alteration, and Relation to Mineralisation, Economic Geology, Vol. 94, 1093-1114.

Boyle, R.W., 1982. Geochemical prospecting for Thorium and Uranium deposit, Developments in Economic Geology. No 16, Elsevier, Amsterdam. 498pp.

Durham, K.M. and Pickett, C.R., 1966. Oil mining lease 47, Lekki Corehole programme (February-April 1966). Unpubd. Rept. Tennesse Nig. Inc.

Enu, E.I., 1985. Textural characteristics of the Nigerian tar sands, Sedimentary Geology, Vol. 44, 65-81.

Funtua, I.I., 1994. Distribution of Radium-226 around Kanawa uranium mineralization, N.E. Nigeria, Journal of Minning and Geology. Vol. 33 No. 2, 57-61.

Gates, A.E. and Gundersen, L.C.S., 1992. Sensitivity of soil radon to geology and the distribution of radon and uranium in the Hilyas zone area, Virginia, In Gates, A.E. and Gundersen, L.C.S., (eds). Controls on Radon: Boulder, Colorado, Geological Society of America Special Paper 271. pp. 17-27.

IAEA., 1989. International Atomic Energy Agency, Measurement of radionuclide in food and the environment. A Guidebook, Technical report series No 295 (IAEA. Vienna)

ICRP, 2002. Uranium information center: Radiation and life, http:// www.uic.com.au/ral.htp, 88pp

Klemme, H.D., 1975. Geothermal gradients, heat flow and hydrocarbon recovery, In: A.G. Fisher and S. Judson (editors), Petroleum and Global Tectonics. Princeton, New Jersey, Princeton University Press, 251-304

National Research Council., 1988. Health risks of radon and other internally deposited alpha emitters: Reports of the Committee on the Biological effects of ionizing Radiation (BEIR IV), National Reseacrch Council: Washington DC, National Academy Press, 624pp.

Omatsola, M.E. and Adegoke, O.S., 1981. Tectonic evolution and Cretaceous stratigraphy of the Dahomey Basin. Nigerian Journal of mining and Geology, Vol. 18, No. 1, 130-137.

Oyawale, A.A., 2003. Baseline studies on the Radioactivity of the Tar-Sand Deposits of Ondo State, southwestern Nigeria. Unpublished M.Sc. Thesis, O.A.U., Ile-Ife. 124pp. 